\title{
ABUNDANCE OF ZOOPLANKTON IN RAMSAGAR-DIGHI, DINAJPUR, BANGLADESH
}

\author{
Sarmin Akther*, Ashaduzzaman and Md. Jakir Hossain \\ Department of Zoology, University of Rajshahi, Rajshahi-6205, Bangladesh.
}

\begin{abstract}
The present study was carried out from May, 2011 to March, 2012 which deals with the abundance of zooplankton in Ramsagardighi, Dinajpur, Bangladesh. A total of 27 species of 21 genera were recorded in which rotifers were more abundant with 9 genera and 12species followed by copepods with 6 genera and 7 species and cladocerans with 5 genera and 7 species from the study area. A crustacean, nauplius larva was also recorded from the study area. Monthly fluctuation of some physico-chemical parameters was also noted.
\end{abstract}

Key words: Abundance, Zooplankton, Ramsagar dighi.

\section{INTRODUCTION}

Bangladesh is a land of aquatic ecosystem which is abundant with different kinds of ponds, rivers, canals, lakes, haors, baors and dishes (Akonda 1989) where the aquaculture is a profitable business. These aquatic environments support various communities of living organisms. They constitute the biotic load of a pond among which planktons are the vital constituents. Plankton designates the community of pelagic organisms, composed of various groups, which are in suspension in water and hence restricted mobility, often less than that of the water which carried (Declince 1992). Plankton is divided into phytoplankton or photosynthetic organisms and zooplankton or heterotrophic organisms. Zooplankton is the organisms that are identified as important components of aquatic ecosystems. They help in regulating algal and microbial productivity through grazing and in the transfer of primary productivity to fish and other consumers (Dejen et al. 2004). Zooplankton distribution within ponds is non-homogenous form. In the fish ponds, some species were mainly found in the littoral, while others selected limonitic waters (Verreth 1990). Their distributions are probably related to food availability and avoidance of predators. Distribution varies with time, due in particular, to vertical migration, which is an almost universal phenomenon. The archetypical form of vertical migration is a swimming movement to deep water during the day and an active ascent towards the surface during the night (Declince 1992). Zooplankton plays an important role in indicating the water quality, eutrophication status and productivity of a freshwater body. The planktons not only increase fish production but also help in bioremediation of heavy metals and other toxic

* Corresponding author: sarmin hamim @gmail.com

(C) 2015 Zoological Society of Bangladesh DOI: 10.3329/bjz.v43i2.27400 
material. Plankton can also act as biomarker for water quality assessment for fish production (Arunava Pradhan 2008). The abundance of zooplankton in a water body is regarded as an indicator of productivity. Both the qualitative and quantitative abundance of zooplankton in a fish pond are of great importance in managing the successful aquaculture operations, as they vary from location to location and pond to pond within the same location even within similar ecological conditions (Boyd 1982). Zooplanktons are the main sources of natural food for fish and shellfish which is directly related to the survival and growth and these are the base of food chains and food webs in all aquatic ecosystems. They also play a major role in recycling nutrients as well as cycling energy within their respective environments. Zooplanktons are an essential food item of omnivorous and planktivorous fishes (Alam et al. 1987) and the most essential for larvae culture (Bardach et al. 1972). In freshwater ecosystem zooplanktonic organisms are important food sources for many aquatic animals specially fishes. The main for major carps like rui , catla and their hybrids were found to be planktonivors in origin (Mozumder and Naser 2009). The juveniles of some these fishes are obligate zooplanktivores (Mwebaza-Ndawula 1994) and depend solely on zooplankton for their survival. In order to fisheries development and to increase the present production level, proper and scientific management is essential to assess the distribution and abundance of zooplankton in the water body. Since the zooplanktons are the primary sources of natural foods for fishes, therefore it is necessary to study the abundance of zooplanktons in the water body to make the aquaculture more profitable. Abundance of zooplanktons in a water body indicates that whether the supplementary feed is necessary to supply in the corresponding fish ponds or not. And thus the abundance of zooplanktons may reduce the cost of aquaculture. Ramsagar-Dighi is a larger historical man made pond of Bangladesh. But there is a little work has been done on the study of zooplankton population. Therefore the present study was designated to assess the abundance of zooplanktons as fish food in RamsagarDighi, Dinajpur, Bangladesh to reduce the cost of aquaculture and make the aquaculture profitable.

\section{MATERIAL AND METHODS}

Ramsagar-Dighi is located at Tajpur village in Dinajpur district, Bangladesh. This reservoir is mainly used for domestic work, aquaculture and also tourist's attraction. The zooplankton samples were collected twice in month between 7 to 8 AM by using plankton net of $64 \mu / \mu \mathrm{m}$ mesh size for a period of 11 months from May, 2011 to March, 2012. The collected samples were kept in plastic bottles containing 4\% formaldehyde. Zooplankton identification is done by following systematic keys of Pennak (1978), Edmondson (1992), Battish (1992) and Altaff (2004). Main characters are considered for identification as lorica, corona and type of trophi for rotifers; antennules, post abdomen, number and arrangement of spines, location of lateral setae and rostrum for cladocera; antennules, antenna, caudal setae, and endopodite for copepoda and antenna, valve shape and setae for ostracods. Population density was quantified by drop count method of Lackey (1938). 


\section{RESULTS AND DISCUSSION}

A total of 21 genera, including 27 species of zooplankton were recorded during the period of May, 2011 to March, 2012, which is represented below. Highest zooplankton density was observed in the month of June and lowest one was recorded in the month of March during the study period of 11 months from May, 2011 to March, 2012 (Table 1).

Table 1. Monthly average fluctuation of Zooplankton (units/1) in the study area of Ramshagardighi from May, 2011 to March, 2012

\begin{tabular}{lll}
\hline Year & Month & Zooplankton (units/1) \\
\hline & May & 4960 \\
& June & 5675 \\
& July & 5220 \\
& August & 3240 \\
& September & 2585 \\
& October & 3635 \\
& November & 5245 \\
& December & 3960 \\
& January & 2850 \\
& February & 2765 \\
Mean \pm SD & March & 1560 \\
\hline
\end{tabular}

The Rotifers, cladocerans, copepods and nauplius larvae were found to inhabit under the physico-chemical conditions of the water like water temperature, $\mathrm{pH}$, free carbon dioxide and total dissolved oxygen of the study area were mentioned in the Table 2.

Rotifera: Rotiferans were the dominant group among the zooplanktons that were recorded as 12 species belonging 9 genera during the study period. Brachionus was the dominant form of the total rotifers in the study area and Keratella, Testudinalla, Asplanchna, Fillinia, and Lapadella were less dominant in comparison to first one during the study period (Table 3 and Fig. 1). Rotifers play a vital role in the trophic tiers of freshwater impoundments and served as living capsule of nutrition (Kumar et al. 1999). Taxonomic dominance has been reported in several water bodies (Kudari et al. 2005, Kanagasabhapati and 
Table 2. Monthly average fluctuation of water temperature, $\mathrm{pH}$, free carbon dioxide and total dissolved oxygen in Ramshagar-dighi, Dinajpur, Bangladesh from May, 2011 to March, 2012

\begin{tabular}{|c|c|c|c|c|c|c|c|c|c|c|c|c|}
\hline \multirow{3}{*}{ 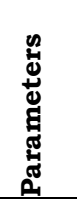 } & \multicolumn{11}{|c|}{ Months } & \multirow[t]{3}{*}{ Mn \pm SD } \\
\hline & \multicolumn{8}{|c|}{2011} & \multicolumn{3}{|c|}{2012} & \\
\hline & May & June & July & Aug & Sept & Oct & Nov & Dec & Jan & Feb & Mar & \\
\hline WT & 29.1 & 28.3 & 28.5 & 27.1 & 28.5 & 27.7 & 23.8 & 17.5 & 15.6 & 20.7 & 24.6 & $24.6 \pm 4.76$ \\
\hline$P^{\mathrm{H}}$ & 7.3 & 6.9 & 7.9 & 8.2 & 7.8 & 7.1 & 7.7 & 7.2 & 7.9 & 8.1 & 8.3 & $7.7 \pm 0.48$ \\
\hline $\mathrm{fCO}_{2}$ & 2.2 & 1.8 & 0.0 & 0.0 & 1.2 & 0.0 & 0.7 & 2.2 & 0.0 & 0.0 & 1.3 & $0.85 \pm 0.92$ \\
\hline DO & 4.9 & 5.8 & 4.2 & 3.9 & 4.4 & 5.6 & 5.1 & 4.3 & 4.5 & 4.1 & 4.4 & $4.6 \pm 0.6$ \\
\hline
\end{tabular}

Rajan 2010). This pattern is common in lakes, ponds, reservoirs and rivers (Neves et al. 2003). The population density of rotifers was rich in June (5675 unit/1) and less in March (1560 unit/1). George (1964) and Michael (1968a) from Indian water bodies and Ali et al. (1983) from a fish pond at Tongi and Ali et al. (1989) in the pond of Dahka University campus in Bangladesh conformed that Brachionus falcatus and B. plicatilis were perennial where Brachionus sp was frequent in occurrence but B. forficula along with Keratella sp., Lepadella sp. and Asplanca sp were found very rare. The number of Rotifers was dominated in the present study area may be due to the higher content of organic matter of dead and decaying vegetation. This finding is supported by Majagi and Vijaykumar (2009).

Cladocera: Cladocerans are the most useful and nutritive group of crustaceans for higher members of fishes in the food chain. In the present study, a total of 7 species were recorded. The cladocerans constituted the second dominant group that were found 7 species belonging 5 genera during the study period (Table 3 and Fig. 1). The population densities of cladocera were higher in monsoon (39 unit/1) and lower in winter (35 unit/1). Abundance has also been earlier reported in monsoon season and lower in summer by Pawar and Pulle (2005) in Pethwadaj dam of Nanded district. The dominant species among the cladocerans were Daphnia followed by Diaphanosoma and Moina persisting in the study area. As a second dominant group, cladocera possessed completely a seasonal abundance among the zooplankton. This study was strengthen by Krishnamoorthi and Visweswara (1964) from India, Patra and Azadi (1987), Bhuiyan and Nessa (1998a) and Islam et al. (2000) from Bangladesh. 

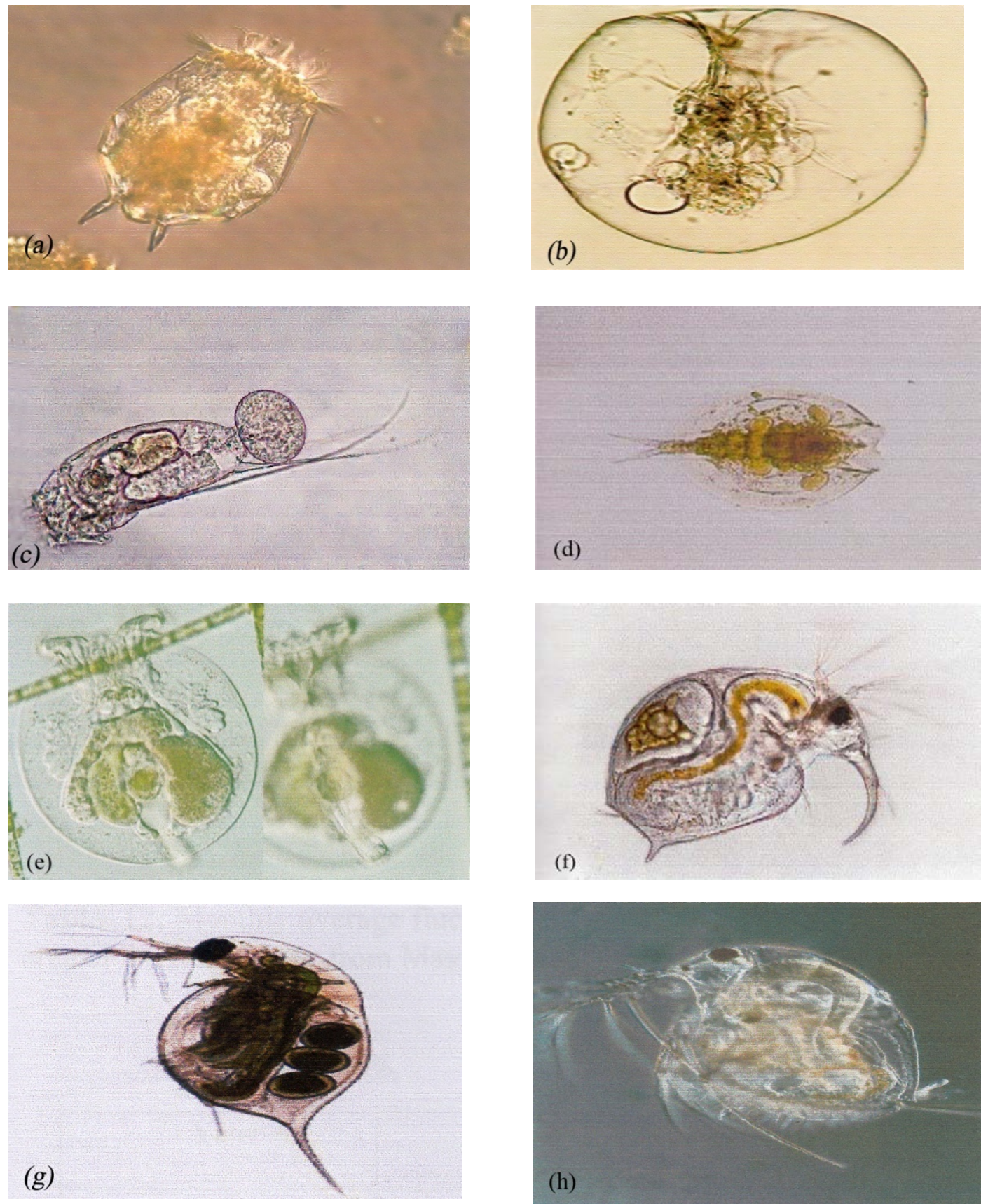

Fig. 1. Photographs of Asplanchna (a), Brachionus angularis (b), Filinia (c), Lepadella cristata (d), Testudinella (e), Bosmina (f), Daphnia pulex (g) and Diaphanosoma (h),

Copepoda: The Copepoda were the third dominant group of zooplankton with 7 species of 6 genera were available during the study period. Mesocyclops 
showed the dominancy followed by Cyclops and Macrocyclops in the study area (Table 3 and Fig. 2).Diaptomus, Eudiaptomum etc. also found in the study area during the study period of May, 2011 to March, 2012.

Abundance of copepoda was observed in Roshanara tank from India by George (1966). Islam et al. (2000) found the peak persistence of copepods in the pond of Bangladesh. All species were reported by various authors from Bangladesh notably Das and Bhuiyan (1974), Khan et al. (1990) from Buriganga River, Bhuiyan and Sen (1983) from Foy's Lake, Chowdhury et al. (1989) from fish pond, Ali et al. (1989) from Dhaka University pond and Bhuiyan and Nessa (1998a) in Rajshahi University pond. Copepods showed higher population density in summer (447 unit/1) and lower in mansoon (32 unit/1). This pattern of seasonal fluctuation of copepods has also been observed by Mahor (2011) in Trigha reservoir of Gwalior, suggesting their preponderance in higher trophic state of water. Similar observations were made by Somani and Pejavar (2004) in Masunda Lake Abundance of copepods like Mesocyclops, Cyclops and Macrocyclops in the present study may be due to the higher contents of organic matter.

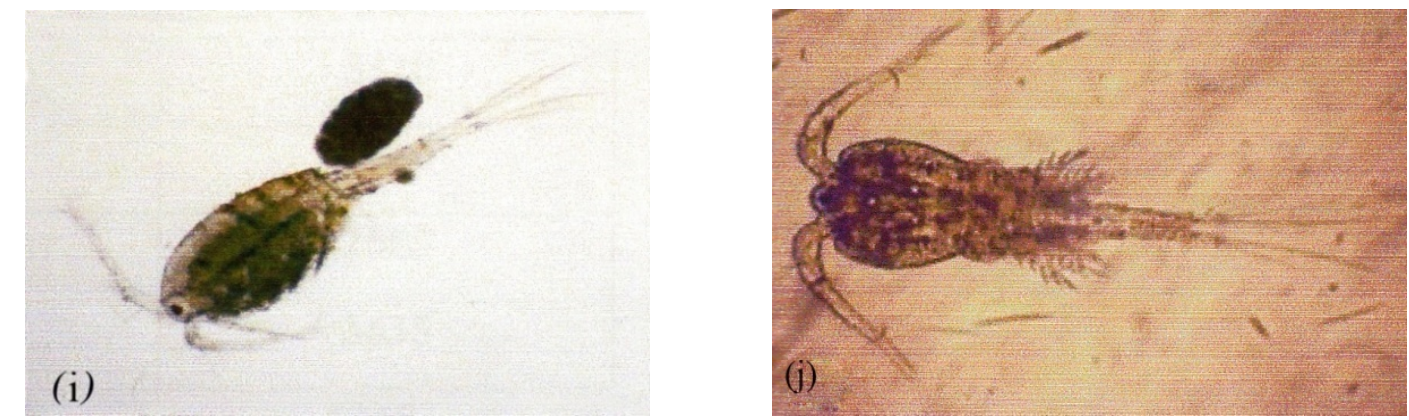

Fig. 2. Photographs of Cyclops (i) and Mesocyclops (j).

Crustacean Larvae: Crustacean larvae comprised mainly nauplius larvae which is the good sources of primary food for fishes in the study area observed during the study period (Table 3)

Table 3. A checklist of zooplanktons from Ramshagar-Dighi, Dinajpur, Bangladesh during the investigation period of May, 2011 to March, 2012.

\begin{tabular}{|c|c|c|}
\hline SL. No. & Group & Genera/Species \\
\hline 1. & & Asplanchna sp. \\
\hline 2. & & Brachionus angularis \\
\hline 3. & & Brachionus caudatus \\
\hline 4. & & Brachionus falcatus \\
\hline 5. & Rotifera & Brachionus forficula \\
\hline 6. & & Filinia sp. \\
\hline
\end{tabular}




\begin{tabular}{|c|c|c|}
\hline SL. No. & Group & Genera/Species \\
\hline 7. & & Hexarthra sp. \\
\hline 8. & & Keratella sp. \\
\hline 9. & & Lepadella cristata \\
\hline 10. & & Monostyla sp. \\
\hline 11. & & Polyarthra sp. \\
\hline 12. & & Testudinella sp. \\
\hline 13 & & Bosmina sp. \\
\hline 14 & & Daphnia lumholtzii \\
\hline 15 & Cladocera & Daphnia magna \\
\hline 16 & & Daphnia pulex \\
\hline 17 & & Diaphanosoma sp. \\
\hline 18 & & Macrothrix rosea \\
\hline 19 & & Moina sp. \\
\hline 20 & & Cyclops leukartii \\
\hline 21 & & Cyclops sp. \\
\hline 22 & & Diaptomus sp. \\
\hline 23 & Copepoda & Eudiaptomus sp. \\
\hline 24 & & Heliodiaptomus latift \\
\hline 25 & & Macrocyclops sp. \\
\hline 26 & & Mesocyclops sp. \\
\hline
\end{tabular}

The immature zooplanktonic form of nauplius larva that was persisted as single peak observed by George (1964) in Delhi, India and Michael (1968a) in a tropical pond. The peak abundance of zooplanktons in the present investigation was recorded in the month of June, 2011 and lowest one was recorded in the month of March, 2012 during the study period. This may be due to the favourable conditions of physico-chemical parameters and the availability of nutrients in the ponds. Such single peak was recorded by George (1964) and Miah et al. (1981) from a fish pond of Mymensingh where the maximum population of zooplankton observed almost round the year. Krishnamoorthi and Visweswara (1964) recorded maximum of zooplankton population in February, March and April in the year of 1962 and January and December in the year of 1961 in an Indian lake. Patra and Azadi (1987) found the peak in winter from Halda River in Bangladesh. Islam et al. (2000) also found the peak in winter from a pond in Rajshahi.

Our results are in close conformity with those reported above. However, more comprehensive works are to be solicited. 


\section{CONCLUSION}

The abundance of zooplankton indicated that the Ramshagardighi is considerably productive. The abundance of zooplanktonic population showed that natural foods for fishes are available in the study area where suitable and cost reductive aquaculture can be solicited.

Acknowledgements: The authors are thankful to the Chairman, Department of Zoology, University of Rajshahi for providing academic support during this research work and also thankful to Meteorological regional station, Dinajpur for their kind co-operation during the study period.

\section{LITERATURE CITED}

AKONDA, A.W. 1989. A Directory of Asian Wetlands. IUCN, Gland, Switzerland and Cambidge, Bangladesh; pp. 541-581.)

ALAM, A. K. M. N., ISLAM, M. A., MOLLAH, M. F. A. and HAQUE, M. S. 1987. Status of zooplankton in newly constructed ponds and their relation to some meteorlogical and limnological factors. Bangladesh Journal of Fisheries 14(1): 83-88

ALI, S., RAHMAN, A. K., RAHMAN, A. R., PATWARY, A. R. and ISLAM, K. H. R. 1983. Studies on the diurnal variation in physico-chemical factors and zooplankton in a fresh water pond. Bangladesh J. Fish. 2-5(1-2): 15-23.

ALI, S., SHAHA, S. and MAHMUD, N. 1989. Studies on the physico-chemical aspects of Maheshkhali Channel, Bay of Bengal. Dhaka University Studies B. 33(1):43-49.

ALTAFF, K. 2004. A Manual of Zooplankton, Sponsored by the University Grant commission, New Delhi.

ARUNAVA PRADHAN 2008. Phytoplankton Diversity as Indicator of Water Quality for Fish Cultivation. American Journal of Environmental Sciences 4(4): 406-411.

BARDACH, E. J., RYTHER, H. J. and MELARNY, O. W. 1972. Aquaculture: The farming and husbandry of freshwater and marine organisms. John-Willey and Sons, New York, USA,

BATTISH, S. K. 1992. Freshwater Zooplankton of India. Oxford and IBH Publishing Co. Pvt. Ltd., New Delhi; 1-4, pp. 233.

BHUIYAN, A. M. and SEN, H. 1983. Cladocera of Foys lake. Chittagong Univ. Stud.(b). 7(2): 29-35.

BHUIYAN, A. S. and NESSA, Q. 1998a. Seasonal variation in the occurrence of some zooplankton in a fish pond. Bangladesh J. Fish. Res. 2(2): 201-203.

BOYD, C. E. 1982. Water quality management of pond fish culture. Elsvier Sci. Pub. Co . Amsterdam- Oxford, New York; PP. 318.

CHOWDHURY, A. N., BEGUM, S. and SULTANA, N. 1989. Occurrence and seasonal variation of zooplankton in a fish pond in relation to some physico-chemical factors. Bangladesh J. Zool. 17(2): 101-106.

DAS, N.G. and BHUIYAN, A. L. 1974. Limnoplankton of some inland waters of Dhaka city. Bangladesh J. Zool. 2(1): 27-42. 
DECLINCE, G. 1992. The ecology of the fish pond ecosystem. (pp. 127-187). Kluwer Academic Publishers. http://www.dx.doi.org/10.1007/978-94-017-3292-5_4

DEJEN, E., J. VIJVERBERG, L. NAGELKERKE and F. SIBBING. 2004. Temporal and spatial distribution of microcrustacean zooplankton in relation to turbidity and other environmental factors in large tropical lake (L. Tana, Ethiopia). Hydrobiologia 513: 39-49.

EDMONDSON, W.T. 1992. Freshwater Biology, 2nd Edition, John Willey and Sons. London. Pp. 657-734.

GEORGE, M. G. 1964. Comperative plankton ecology of five fish tanks in Delhi, India. Hydrobiol. 27: 81-108.

GEORGE, M. G. 1966. Comparative plankton ecology of five fish tanks in Delhi, India. Hydrobiol. 27(1 \&2): 81-108.

ISLAM, M. N., KHAN, T. A. and BHUIYAN, A. S. 2000. Ecology and seasonal abundance of some zooplankton of a pond in Rajshahi. Univ. J. Zool. Rajshahi Univ. 19: 25-32.

KANAGASABHAPATI, V. and RAJAN, M. K. 2010. A Preliminary survey of plankton in Irrukkangudi reservoir, Virudhnagar District. T. N. J. of Phytology, 2 (3): 63-72.

KHAN, S. M., MUNZURUL. H., AZIZ, K. M. S., MORSHED, M. G. and SHAFI, M. 1990. Seasonal variations in physico-chemical conditions of Dhanmondi lake water. Bangladesh J. Zool. 8(1): 61-66.

KRISNAMURTHY, K. P. and VISVESVARA, G. 1964. Hydrobiological studies in Gandhisagar (Jumma Tank). Seasonal variation in plankton (1961-1962). Hydrobiolologia, 27:501-514

KUDARI, V.A., KADADEVARU, G. G. and KANAMADU, R. D. 2005. Zooplankton composition in some ponds of Haveri district, Karnataka. Zoo's Print Journal 20 (12):2094-2099.

KUMAR, S., ALTAFF, R. K. and RAGHUNATHAN, M. B. 1999. New record of a Chydorid Cladoceran, pleuroxuy Aduncus jurine (1920), from Chennai, South India, with the description of the Development stages. J. Aqua. Biol. 14 (1\& 2):7-10.

LACKEY, J. B. 1938. The manipulation and counting of river of river plankton and changes in some organisms due to formalin preservation. Public Health Repts. 53:2080-2093.

MAHOR, R. K. 2011. Diversity and seasonal fluctuation of zooplankton in freshwater reservoir Tighra Gwalior (M.P.). Internat. Referred Research Journal 1(17):47-48.

MAJAGI, G. and VIJAYKUMAR, K. 2009. Ecology and abundance in Karanja reservoir. Environ. Monit. Asses.152:137-144

MIAH, M. I., BHUIYAN, N. I. and DEWAN, S. 1981. A comparative study of the rate of growth of major in relation to physico-chemical and biological factors. Proc. $3^{\text {rd }}$ Nat. Zool. Conf. 215-223.

MICHAEL, R. G. 1968a. Studies on the zooplankton of a tropical fish pond. Hydrobiol. 32: 47-68. 
MOZUMDER P. K. and NASER M. N. 2009. Food and feeding habit of Catla (Catla catla Ham.), Rui (Labeo rohita Ham.) and Catla - rui hybrids. Bangladesh J. Zool. 37(2):303-312.

MWEBAZA-NDAWULA L. 1994. Changes in relative abundance of zooplankton in two northern Lake Victoria, East Africa. Hydrobiologia 272: 259-264.

NEVES, I. F., ROCHA, O., ROCHA, K. F. and PINTO, A. A. 2003. Zooplankton community structure of two marginal lakes of the river Cauba (Mato Grasso, Brazil) with analysis of Rotifera and Cladocera diversity Brazil. Journal of Biology 63(3):329343

PATRA, R. W. R. and AZADI, M. A. 1987. Ecological studies on the planktonic organisms of the Halda River. Bangladesh J. Zool. 15(2): 109-123.

PAWAR, S. K. and PULLE, J. S. 2005. Qualitative and quantitative study of zooplankton in Pethwadaj Dam,Nanded district (Maharashtra) India. Journal of Aquatic Biology 20 (2):53-57.

PENNAK, R. W. 1978. Freshwater Invertebrates of United States. 2nd Edition, John Wiley and Sons Inc. pp. 421.

SOMANI, V. and PEJAVAR, M. 2004. Crustacean zooplanktons of Lake Masunda, Thane, Maharashtra. J. Aqua. Biol. 1(19):57-60.

VERRETH, J. 1990. The accuracy of population density estimates of a horizontally distribute zooplankton community in Dutch fish ponds. Hydrobiologia 203:561.

(Manuscript received on 4 May, 2015; revised on 8 October 2015) 